\title{
SEKOLAHRUMAH (HOMESCHOOLING) SEBAGAI BENTUK PENDIDIKAN NON FORMAL
}

\author{
Oleh: Syahwani Umar ${ }^{1}$
}

\begin{abstract}
Abstrak: Keberadaan pendidikan formal dan nonformal yang ada sekarang ini dirasa belum cukup, maka pada dasawarsa terakhir ini muncul bentuk penyeleggaraan pendidikan yang dikenal dengan sebutan homeschooling atau sekolahrumah yaitu suatu bentuk pendidikan yang dilakukan oleh orang tua dengan menggunakan rumah sebagai basis pendidikannya. Keberadaan sekolahrumah diharapan dapat mengembangkan potensi peserta didik sesuai dengan tingkat kecerdasan, kebutuhan dan bakat yang dimiliki.
\end{abstract}

Kata kunci: Sekolahrumah, Pendidikan Non Formal, Potensi Diri.

\section{A. Pendahuluan}

Pendidikan memiliki peranan strategis dalam menyiapkan generasi berkualitas untuk kepentingan bangsa dan negara. Bagi orang tua, masyarakat dan bangsa, peme-nuhan akan pendidikan menjadi suatu kebutuhan yang mendasar. Karena pendidikan dijadikan program utama dalam membentuk sumberdaya manusia (human resources) yang berkualitas yang dapat diandalkan bangsa dan negara untuk menyumbangkan pemikiran, keterampilan, dan keahliannya. Secara faktual, pendidikan dapat mening-katkan kesejahteraan sosial ekonomi suatu bangsa hal ini tercermin dari peningkatan pendapatan warga negara. Dalam era globalsasi, keunggulan kompetitif (competitive edvance) suatu bangsa dalam bidang ilmu pengetahuan merupakan faktor dominan untuk melakukan percepatan kemajuan bangsa.

Institusi pendidikan khususnya pendidikan formal (persekolahan), pada akhir-akhir ini mendapat kritikan dan sorotan tajam dari ahli pendidikan, masyarakat serta pemerhati pendidikan baik melalui media masa maupun dalam seminar-seminar pendi-dikan. Masalah dalam pendidikan antara lain bahwa pendidikan sekolah kurang atau tidak dapat menjawab tantangan pembangunan yang memerlukan tenaga-tenaga yang mandiri dan mempunyai mental kewirausahaan. Pada akhir-akhir ini ada

${ }^{1}$ Syahwani Umar adalah dosen Jurusan Ilmu Pendidikan FKIP-Untan Pontianak 
keraguan terhadap sekolah yang hanya mampu mengajarkan konsepkonsep kompetensi setiap bidang studi namun kurang membekali sikap dan mental kemandirian peserta didik untuk dapat hidup di kemudian hari.

Dikemukakan oleh Reimer (Soedomo,1997: 2) bahwa peradaban manusia "mo-dern" pada dasarnya terkungkung dalam penjara suatu sistem kelembagaan yang disebut sekolah. Memang harus diakui, sebagian peningkatan mutu hidup yang berhasil diraih banyak orang karena layanan lembaga persekolahan. Meningkatnya pengetahuan masyarakat, berakibat pada peningkatan kebutuhan hidup termasuk layanan pendidikan yang semakin berkualitas dan beragam. Lembaga pendidikan formal pada kenyataannya tidak mampu menjawab dan mengakomodasi seluruh kebutuhan dan aspirasi yang berkembang di masyarakat. Bahkan praktek pendidikan cenderung tidak memperhatikan pebedaan individu terutama dalam hal kecerdasan, bakat, motivasi ataupun kemampuan masing-masing peserta didik. Pada praktek pendidikan formal, peserta didik diharuskan mengikuti mata pelajaran yang sudah didesain dalam kurikulum tanpa mempertimbangkan karaketristik peserta belajar. Karena itu, beberapa alternatif untuk memenuhi kebu-tuhan peserta didik, orang tua dan masyarakat dirancang beberapa program pendidikan non formal sebagai suplemen pendidikan formal yang sampai saat ini telah dirasakan manfaatnya.

Keberadaan pendidikan formal dan nonformal yang ada sekarang ini dirasa be-lum cukup, maka pada dasawarsa terakhir ini muncul bentuk penyeleggaraan pendidikan yang dikenal dengan sebutan homeschooling atau sekolahrumah yaitu suatu bentuk pendidikan yang dilakukan oleh orang tua dengan menggunakan rumah sebagai basis pendidikannya. Keberadaan sekolahrumah diharapan dapat mengembangkan potensi peserta didik sesuai dengan tingkat kecerdasan, kebutuhan dan bakat yang dimiliki.

\section{B. Pengertian Homeschooling (sekolah rumah)}

Sekolah rumah dapat diartikan sebuah model pendidikan dimana sebuah keluarga memilih untuk bertanggung jawab sendiri atas pendidikan anak-anaknya dan mendidik anaknya dengan menggunakan rumah sebagai basis pendidikan. Dengan demikian, orangtua dalam sekolahrumah bertanggungjawab secara aktif atas proses pendi-dikannya. Yang dimaksud bertanggung jawab secara aktif di sini adalah keterlibatan penuh orang tua pada proses penyelenggaraan pendidikan, mulai penentuan tujuan pendidikan, kompetensi, ataupun keterampilan yang 
akan dicapai, kurikulum dan materi pembelajaran sampai pada metode belajar serta praktik belajar anak didik.

\section{Homeschooling Versus Sekolah}

Sekolah rumah termasuk model pendidikan yang digunakan sebagai alternatif institusi sekolah. Sebagai sebuah model pendidikan anak, homeschooling memiliki per-samaan-persamaan dengan sekolah, antara lain sama-sama bertujuan untuk mengantar-kan anak-anak untuk mengoptimalkan potensinya. Keduanya merupakan sarana untuk mengantarkan anak pada tujuan pendidikan. Tujuan pendidikan sebagaimana dinyata-kan dalam Undang-Undang No.20 tentang Sisdiknas Pasal 3 adalah untuk mengembangkan potensi peserta didik agar menjadi manusia yang beriman dan bertakwa kepada Tuhan Yang Maha Esa, beraklak mulia, sehat, berilmu, cakap, kreatif, mandiri, dan menjadi warga negara yang demokratis serta bertanggung jawab. Sedangkan pendidikan diartikan sebagai usaha sadar dan terencana untuk mewujudkan suasana belajar dan proses pembelajaran agar peserta didik secara aktif mengembangkan potensi dirinya untuk memiliki kekuatan spiritual keagamaan, pengendalian diri, kepribadian, kecerdasan, akhlak mulia, serta keterampilan yang diperlukan dirinya, masyarakat, bangsa, dan negara. Sedangkan sekolah adalah sistem yang digunakan untuk mencapai tujuan pendidikan.

Selain beberapa persamaan, homeschooling dengan sekolah memiliki perbedaan antara lain;

1. Pada sistem sekolah tanggung jawab pendidikan anak didelegasikan orang tua kepada guru dan sekolah. Pada homeschooling, tanggung jawab pendidikan anak sepenuhnya berada di tangan orang tua.

2. Pada sistem sekolah, peran orang tua dan keluarga relatif kecil karena pendidik-an dijalankan oleh sistem sekolah dan guru. Pada homeschooling, peran orang tua dan anak sangat menentukan keberhasilan pendidikan, walaupun orang tua tidak harus mengajarkan sendiri kepada anak-anaknya. Arah pendidikan ditentukan oleh kebijakan orang tua bersama anak-anak sekolahrumah.

3. Model belajar di sekolah, sistem yang ada sudah mapan. Orang tua tinggal me-milih sebuah model sekolah yang diminati dan kemudian mengikuti proses pen-didikan yang dijalankan untuk anak-anaknya. Namun pada homeschooling, di-butuhkan komitmen dan kreativitas orang tua untuk melaksanakan sekolahru-mah. Keluarga 
homeschooling dapat memilih sebuah paket pendidikan tertentu atau melakukan penyesuaian menurut kebutuhannya.

4. Sistem sekolah terstandarisasi untuk memenuhi kebutuhan anak secara umum, sementara sistem pada homeschooling disesuaikan menurut kebutuhan anak dan kondisi keluarga.

5. Pengelolaan di sekolah terpusat, antara lain kurikulumnya telah ditetapkan sera-gam untuk seluruh siswa. Pengelolaan terdesentralisasi tergantung keluarga homeschooling. Keluarga homeschooling memilih sendiri kurikulum dan materi ajar untuk anak-anaknya.

6. Pada sekolah, jadual belajar telah ditentukan dan seragam untuk seluruh siswa. Pada homeschooling, jadual belajar fleksibel tergantung kesepakatan antara orang tua dan anak.

Mengkaji kesamaan dan perbedaan homeschooling dan sekolah, kita dapat mengetahui kelebihan dan kekurangan yang ada pada praktek sekolahrumah dibandingkan dengan sistem sekolah pada masa sekarang.

\section{Pelaksanaan sekolahrumah}

Sesuai dengan nama jenis pendidikan sekolahrumah lebih populer disebut home-schooling, kadang disebut home education atau home-based learnig, maka proses belajar-mengajar dipimpin oleh orang tua, bukan berarti semua materi pelajaran disampaikan oleh orang tua. Praktek sekolahrumah pada tingkat awal (pra sekolah dan SD kelas rendah) materi pelajaran relatif sederhana dapat disampaikan oleh orang tua sendiri. Pada tingkat yang lebih tinggi dan materi pelajaran sudah semakin rumit dan komplek, maka orang tua dapat berperan sebagai kepala sekolah. Sebagai kepala sekolahrumah, peran orangtua bertanggungjawab atas keseluruhan proses belajar anak. Kepala sekolah dapat merangkap sebagai guru.

Proses homeschooling berpusat di rumah, namun demikian para orangtua dapat menggunakan sarana umum untuk pendidikan anaknya. Tempat yang memungkinkan untuk belajar antara lain, perpustakaan, museum, taman, pameran, perkebunan. Selain itu homoschooling dapat menggunakan guru privat, atau tutor yang didatangkan untuk melayani pendidikan.

Jika ingin melaksanakan homeschooling dengan model sekolah di rumah (school at home) berdasarkan sistem pendidikan nasional, maka perlu memperhatikan ketentu-an-ketentuan Departemen Pendidikan Nasional (Depdiknas) mengenai penyelenggaraan sekolah rumah. 


\section{Mencari kurikulum Depdiknas}

Apabila sudah menentukan pilihan sekolahrumah berdasarkan sistem pendidikan nasional, maka acuan yang digunakan adalah kurikulum yang dibuat oleh Departemen Pendidikan Nasional (depdiknas) sebagai acuan proses penyelenggaraan sekolahrumah. Dengan mengetahui standar kompetensi yang hendak dicapai, maka dapat merencana-kan proses belajar sehari-hari dengan lebih baik. Kurikulum dimaksud dapat diperoleh dari sekolah, Kantor Dinas Pendidikan nasional setempat, atau dapat diperoleh melalui internet dengan melakukan download secara gratis dari situs www.puskur.net.

\section{Daftarkan Pada Komunitas Homeschooling}

Agar dapat dikui keberadaan penyelenggaraan sekolahrumah yang akan dilak-sanakan, maka daftarkan pada komunitas sekolahrumah, dapat di PKBM terdekat. Pen-daftaran yang dilakukan untuk menjamin legalitas siswa agar dapat mengikuti ujian-ujian yang diselenggarakan oleh Depdiknas.

\section{Buat Program jangka pendek}

Membuat rencana jangka pendek (mingguan atau bulanan) mengenai kegiatan belajar yang akan dilakukan bersama anak-anak. Program mingguan dapat membantu anda menilai efektivitas proses yang sudah dijalani.

\section{Jadualkan Kegiatan Harian}

Dalam perencanaan, buatlah jadual harian sehingga anak-anak dapat mengisi hari-harinya dengan efefktif. Jadual juga berguna untuk membantu anak-anak mengetahui ekspektasi yang diharapkan darin proses belajarnya.

\section{Lakukan kegiatan dengan kesepakatan}

Lakukan semua perencanaan bersama-sama dengan anak-anak. Dengan kese-pakatan bersama, anak akan meningkat rasa memiliki dan tanggung jawabnya. Jika program dan jadual berangkat dari minat dan inisiatif anak, rasa keterlibatan itu akan lebih besar.

\section{Pilih bahan pelajaran yang menarik}

Bahan belajar bisa didapat dari berbagai sumber, misalkan dari radio, televisi, kehidupan nyata di sekitar kita. Bahan belajar tidak harus berasal dari buku pelajaran baru, akan tetapi dapat memanfaatkan buku 
pelajaran yang lama selanjutnya dilengkapi dengan informasi-informasi penting. Yang utama bahwa buku-buku pelajaran masih relevan dan sesuai dengan kurikulum sekolah.

\section{Pilih metode belajar yang sesuai}

Metode belajar yang paling umum dan dikenal adalah membaca, menulis, dan berhitung. Praktek sekolahrumah, dapat menggunakan metode-metode yang paling cocok dengan gaya belajar anak. Anda dapat mengembangkan berbagai model belajar inovatif sesuai dengan kompetensi dasar yang sedang dibahas.

\section{Gunakan Pengalaman sehari-hari}

Peristiwa sehari-hari yang ada di sekitar anak dapat meningkatkan efektivitas sekolahrumah. Semakin dekat materi pelajaran dengan minat dan kebutuhan anak, semakin tinggi daya serap terhadap bahan pelajaran yang sedang dipelajari. Pengalaman sehari-hari akan membuat materi yang dipelajari anak-anak tak hanya berupa konsep dan teori, tetapi benarbenar berguna untuk kehidupan mereka sehari-hari.

\section{Evaluasi}

Setelah membuat rencana dan melaksanakannya, jangan lupa melakukan eva-luasi untuk mengetahui efektivitas kegiatan yang sudah dilakukan. Pelaksanaan evaluasi tidak formal. Bentuknya dapat obrolan di meja makan sambil makan malam. Yang pen-ting, anda dan anak-anak mengetahui apa yang sudah berhasil dan yang perlu diperbaiki di waktu selanjutnya.

\section{Portofolio}

Dokumentasikan proses dan karya-karya yang lahir selama proses pembelajaran. Dokumentasi dapat berupa hasil karya nyata, penyelesaian tugas, jurnal aktivitas yang dibuat oleh orang tua.

\section{E. Penutup}

Anggapan sebagian besar masyarakat sampai saat ini, bahwa model umum pen-didikan paling mapan dan dikenal luas adalah sistem sekolah atau pendidikan formal. Bahkan sekolah dipandang sebagai satusatunya model pendidikan yang ada dan paling menjanjikan. Namun demikian, sebagian masyarakat mulai mempertanyakan keberadaan 
pendidikan sistem sekolah yang seringkali membelenggu anak dalam proses pem-belajaran dengan menyamakan kurikulum dengan seluruh isinya pada setiap anak. Padahal anak mempunyai perbedaan dalam hal minat, kebutuhan, kecerdasan, ataupun bakatnya.

Sekolahrumah atau homeschooling sebagai alternatif yang sudah terbukti dapat memfasilitasi minat, kebutuhan anak sesuai dengan kehidupan nyata di masyarakat dan lingkungan sekitarnya. Praktek homeschooling justru lebih cepat berkembang pada negara-negara maju, ini sebagai bukti bahwa sekolahrumah dapat semakin berperan dalam menyukseskan tujuan pendidikan nasional.

\section{DAFTAR PUSTAKA}

Sumardiono. 2007. Homeschooling A Leap For Better Learning: Lompatan Cara Belajar. Jakarta: PT Elex Media Komputindo.

Jurnal Institut. 2005. Kemana Pendidikan Kita?. Jakarta : LPM Institut UIN Syahid.

Soedomo. 1997. Sekitar Eksistensi Sekolah. Yogyakarta: Penerbit PT Hanindita.

Illich, Ivan. 1984. Bebas dari sekolah. Diterjemahkan oleh Woekirsari. Jakarta: Sinar Harapan 